\title{
Effects of Temperature, Relative Humidity, and Plant Age on Bacterial Disease of Onion Plants
}

\author{
Kim E. Tho, ${ }^{1,2}$ Elizabeth Brisco-McCann, ${ }^{1}$ Prissana Wiriyajitsomboon, ${ }^{1,3}$ and Mary K. Hausbeck ${ }^{1,+}$ \\ ${ }^{1}$ Department of Plant, Soil and Microbial Sciences, Michigan State University, East Lansing, MI 48824, U.S.A. \\ ${ }^{2}$ Division of Research and Extension, Royal University of Agriculture, Phnom Penh 12401, Cambodia \\ ${ }^{3}$ Department of Microbiology, Faculty of Science, Kasetsart University, Bangkok 10900, Thailand
}

Accepted for publication 30 July 2019.

\section{Abstract}

Foliar disease of onion in Michigan, caused by Pantoea agglomerans, Pantoea ananatis, or Enterobacter cowanii, has recently become a concern to producers. The objective of this study was to determine the effect of temperature, relative humidity $(\mathrm{RH})$, and plant age in growth chamber and greenhouse experiments on onion plants inoculated with each pathogen. A significant level of disease resulted from each pathogen at 25 to $30^{\circ} \mathrm{C}$, with strong positive associations detected using regression analysis between the area under the disease progress curve (AUDPC) and temperature. $\mathrm{RH}$ also significantly influenced symptom development. Foliar disease symptoms developed sooner and were more severe when $\mathrm{RH}$ was high (80 to $100 \%$ ) but was limited at $\mathrm{RH}<60 \%$. Significant positive associations between RH and AUDPC, as described by linear regression, were also detected. When 6- to 14 week-old plants were inoculated with each bacterial pathogen, susceptibility increased significantly with age. These results provide insight into the epidemiology of $P$. agglomerans, $P$. ananatis, and $E$. cowanii bacterial pathogens of onions in Michigan and can assist in the development and timing of management strategies.

Keywords: Pantoea agglomerans, Pantoea ananatis, Enterobacter cowanii, temperature, humidity, age-related resistance
Michigan growers produce approximately 37 million kilograms of onion annually, ranking 11th in the United States (NOA 2016). Most of the state's onions are pungent long-day varieties with moderate to long-term storage capabilities (Schwartz 2013). Since 2011, foliar bacterial disease incited by Pantoea agglomerans and $P$. ananatis has occurred in the state's onion fields (Hausbeck 2014; Tho et al. 2019). Symptoms include blight, necrotic tips, streaks, water-soaked lesions, soft rot, bleached tissue, and occasionally plant collapse (Mark et al. 2002). Bacterial disease outbreaks caused by Pantoea spp. can lead to significant yield and quality loss (Schwartz and Mohan 2008).

In Michigan, $P$. agglomerans was first reported in 2013 as the causal agent of stem and leaf necrosis in onion (Tho et al. 2015). $P$. agglomerans was reported to incite leaf blight and bulb rot of onion in Georgia (Edens et al. 2006), New York (Beer et al. 2010), and Pennsylvania (Gugino and Pfeufer 2015; Pfeufer 2014). P. ananatis was first reported in Georgia in 1997 and was associated with losses of up to $100 \%$ (Gitaitis and Gay 1997). Outbreaks of $P$. ananatis in onion have also been reported in Colorado (Schwartz and Otto 2000), New York (Carr et al. 2010), and Michigan (Hausbeck

${ }^{\dagger}$ Corresponding author: M. K. Hausbeck; E-mail: hausbec1@msu.edu

Funding: This research was funded by the State of Michigan Specialty Crop Block Grant, administered by the Michigan Onion Committee for financial support of this research. We thank the United States Agency for International Development (USAID) for providing a graduate assistantship. USAID CGIAR Fund award number BFS-G11-00002 and Food Security and Crisis Mitigation II Grant award number EEM-G00-04-00013.

The author(s) declare no conflict of interest.

(C) 2019 The American Phytopathological Society
2014). The pathogen also causes center rot in storage onions and may increase the potential for colonization by secondary microbes (Stumpf et al. 2017). Walcott et al. (2002) reported that $P$. ananatis can be seed transmitted.

The most common bacterial pathogens associated with symptomatic onion foliage in Michigan include P. agglomerans, $P$. ananatis, and Enterobacter cowanii (Tho et al. 2019). Schwartz et al. (2003) reported that leaf blight, caused by $P$. ananatis, is favored by prolonged periods of rain, high relative humidity $(\mathrm{RH})$, and temperatures of 28 to $35^{\circ} \mathrm{C}$ during the bulbing stage. Prior to the survey by Tho et al. (2019), E. cowanii had not been reported as a pathogen of onions; however, it has been reported to cause leaf spots and blight on Eucalyptus (Furtado et al. 2012) and a tropical rainforest tree species (Brady et al. 2009). Foliar bacterial diseases are relatively new to Michigan's onions, and growers desire additional information to guide their management strategies. Thus, we sought to determine the influence of temperature, $\mathrm{RH}$, and plant age on foliar disease symptoms caused by $P$. agglomerans, $P$. ananatis, and E. cowanii on onion.

\section{Growth Chamber Studies}

Bacterial inoculum. Isolates of $P$. agglomerans (STO14), $P$. ananatis (PA-49), and E. cowanii (PA-42) were obtained in 2014 from symptomatic onion leaves collected from commercial plantings located in the Michigan counties of Ingham, Allegan, and Eaton, respectively. These isolates were confirmed to be pathogenic on onion seedlings and bulbs in a previous study (Tho et al. 2019). $P$. agglomerans and E. cowanii were identified using BIOLOG (Hayward, CA) and sequencing the 16s rDNA using the universal primers (forward, 5'-AGTTTGATCCTGGCTCAG-3'; and reverse, 5' -TACCTTGTTACGACTTCGTCCCA-3') (De Baere et al. 
2004). P. ananatis was identified using the diagnostic primers PanITS1 (5'-GTCTGATAGAAAGATAAAGAC-3') and EC5 (5'TGCCAGGGCATCCACCG-3') (Gitaitis et al. 2002) and sequencing the $16 \mathrm{~s}$ rDNA as described above. The $E$. cowanii isolate was also identified using sequence analysis of $r p o B$ gene (Brady et al. 2008, 2009). The bacteria were grown overnight on nutrient broth yeast extract agar at approximately $30^{\circ} \mathrm{C}$ in the dark. The bacterial suspensions were prepared using sterile deionized water and adjusted to approximately $10^{8} \mathrm{CFU} / \mathrm{ml}$ using a spectrophotometer.

Disease assessment and data analysis. In all experiments, plants were assessed visually for leaf necrosis every other day for 10 days after inoculation (DAI) using a rating of 1 to 5 as follows: $1=<1 \%$, $2=1$ to $10 \%, 3=11$ to $25 \%, 4=26$ to $50 \%$, and $5=>50 \%$ (Schwartz 2013). The area under the disease progress curve (AUDPC) (Jeger and Viljanen-Rollinson 2001) was calculated using Microsoft Excel. The AUDPC data were subjected to splitplot analyses of variance for the temperature and RH studies and randomized completed block design for the effect of plant age by using PROC MIXED in SAS 9.4 (SAS Institute, Cary, NC). The normality assumption of each data set was investigated by observing studentized residual plots, residual versus predicted mean plots, and percentage of residual distribution histogram. Homogeneity assumptions were checked using Levene's test $(P<0.05)$ and comparing Akaike information criterion values from both equal and unequal variance analyses. Means were separated using Fisher's protected least significant difference (LSD) at $(P<0.05)$. Regression analyses were also performed to quantify the relationships between AUDPC data and the effects of temperature, $\mathrm{RH}$, or plant age by using PROC REG in SAS 9.4.

Effect of temperature. 'Bradley' is a widely grown cultivar in Michigan and has been associated with foliar bacterial disease symptoms. Bradley onion seed (Bejo Seeds, Oceano, CA) was planted in 98-cell flats (Hummert International, Earth City, MO) filled with SUREMIX perlite media (Michigan Grower Products, Galesburg, MI) and grown on raised plant benches in the Michigan State University Plant Sciences Research Greenhouses for 7 weeks. Temperature in the greenhouse was maintained at $22.0 \pm 4.3^{\circ} \mathrm{C}$. Plants were fertilized daily with 200 ppm of 20-20-20 Peters watersoluble fertilizer (Scotts Company, Marysville, $\mathrm{OH}$ ). Seedlings were then transplanted into $10-\mathrm{cm}$-square pots and grown in the greenhouse for 1 week prior to inoculation. At 8 weeks, plants with four to five true leaves were inoculated using the method of Wright and Grant (1998) with the following modifications: seedlings were cut back to a height of $15 \mathrm{~cm}$, and bacterial inoculum $\left(10^{8} \mathrm{CFU} / \mathrm{ml}\right)$ was sprayed on the foliage until runoff. Control plants were sprayed with sterile distilled water. Each plant was covered with a clear plastic bag $(20 \times 10 \times 45 \mathrm{~cm})$, and $300 \mathrm{ml}$ of water with soluble fertilizer was added to the bottom of the bag to promote high RH during incubation.

Inoculated plants were placed in growth chambers (model SPC7-2H [BioChambers, Winnipeg, MB, Canada] and Conviron model E7/2 [Controlled Environment, Pembina, ND]) set at $15^{\circ} \mathrm{C}$ (actual: $14.7^{\circ} \mathrm{C} \pm 0.1 \mathrm{SD}$ ), $20^{\circ} \mathrm{C}$ (actual: $19.9^{\circ} \mathrm{C} \pm 0.1 \mathrm{SD}$ ), $25^{\circ} \mathrm{C}$ (actual: $25.2^{\circ} \mathrm{C} \pm 0.1 \mathrm{SD}$ ), or $30^{\circ} \mathrm{C}$ (actual: $30.6^{\circ} \mathrm{C} \pm 0.3 \mathrm{SD}$ ) with a $14-\mathrm{h}$ photoperiod. The experiment was conducted as an incomplete block by repeating the experiment several times until three replicates of each temperature were completed. Each run consisted of two growth chambers and two temperatures. The experiment was a splitplot experimental design with two factors (temperature as the main plot and bacterial species as the subplot). Twenty onion plants (five for each level of subplot) were arranged in a completely randomized design; each plant was considered a subsample. Temperature and $\mathrm{RH}$ within the growth chamber were monitored using a WatchDog sensor (Spectrum Technologies, Plainfield, IL).
Leaf blight symptoms, including water-soaked lesions and necrosis, were observed on inoculated plants. At 25 and $30^{\circ} \mathrm{C}$, disease symptoms were observed at $2 \mathrm{DAI}$; at 15 and $20^{\circ} \mathrm{C}$, symptom development was observed at 4 DAI (Fig. 1). Temperature had a significant effect on the incubation period and disease severity regardless of bacterium. For all pathogens, disease severity increased more rapidly between days 2 and 4 when incubated at 25 or $30^{\circ} \mathrm{C}$ than at 15 or $20^{\circ} \mathrm{C}$ (Fig. 1). Both $P$. ananatis and $P$. agglomerans plants, when incubated at $30^{\circ} \mathrm{C}$, achieved a near maximum disease severity rating of 4.9 by $6 \mathrm{DAI}$; plants inoculated with $E$. cowanii received a disease severity of 5 at 4 DAI (Fig. 1). AUDPC data indicated significant differences among inoculated plants when incubated at different temperatures $(P<0.0001)$ (Table 1). The interaction of temperature and pathogen was also significant $(P=0.0309)$. When plants were inoculated with $P$. agglomerans, mean AUDPC values ranged from 21.1 $\pm 0.7 \mathrm{SE}$ to $37.5 \pm 0.7 \mathrm{SE}$ for inoculated plants incubated at 15 or $30^{\circ} \mathrm{C}$, respectively. AUDPC data for plants inoculated with $P$. ananatis were between $22.3 \pm 1.0 \mathrm{SE}\left(15^{\circ} \mathrm{C}\right)$ and $37.5 \pm 0.7 \mathrm{SE}\left(30^{\circ} \mathrm{C}\right)$, whereas plants inoculated with $E$. cowanii resulted in AUDPC values of $24.9 \pm 0.9 \mathrm{SE}\left(15^{\circ} \mathrm{C}\right)$ to $39.8 \pm 0.4 \mathrm{SE}\left(30^{\circ} \mathrm{C}\right)$ (Table 1$)$. Incubation at 25 or $30^{\circ} \mathrm{C}$ resulted in significantly higher AUDPC values compared with incubation temperatures of 15 or $20^{\circ} \mathrm{C}$ (Fig. 2). Strong relationships for each pathogen were observed between temperature and AUDPC values when linear regression analysis was applied $\left(P\right.$. agglomerans: $y=1.21 x+1.45, R^{2}=0.79$; $P$. ananatis: $y=1.18 x+3.38, R^{2}=0.70 ;$ E. cowanii: $y=1.11 x+$ $\left.8.16, R^{2}=0.77\right)$.

Effect of RH. Plant culture and inoculum preparation were as described in the temperature study. The experiment was conducted in two growth chambers (BioChambers model SPC-7-2H and Controlled Environment model E7/2) maintained at $25^{\circ} \mathrm{C}$ with fluorescent lighting (14 h/day), each set at a different $\mathrm{RH}$. The experiment was arranged as a split-plot design to test $\mathrm{RH}$ of $40 \%$ (actual: $41.7 \pm 1.8 \mathrm{SD}$ ), $60 \%$ (actual: $60.4 \pm 2.0 \mathrm{SD}$ ), $70 \%$ (actual: $71.2 \pm 2.0 \mathrm{SD}$ ), $80 \%$ (actual: $80.0 \pm 0.6 \mathrm{SD}$ ), and $100 \%$ (actual: $97.5 \pm$ 1.7 SD). Five onion plants were inoculated individually with one of the three pathogens, and sterile water served as a control. Plants were arranged in a completely randomized design in each growth chamber. Plants were inoculated using the method previously described but were not enclosed in a plastic bag. Each plant was placed directly onto a $13-\mathrm{cm}$ saucer containing one-half-strength Hoagland solution liquid fertilizer. The experiment was conducted several times to achieve three replicates for each RH level. Temperature and $\mathrm{RH}$ within the growth chamber were monitored using a WatchDog sensor (Spectrum Technologies).

Regardless of RH, all inoculated plants exhibited disease symptoms at 2 DAI (Fig. 3). Disease severity was highest when inoculated plants were incubated under $100 \% \mathrm{RH}$, regardless of the pathogen. E. cowanii inoculation resulted in the highest disease severity ratings at each $\mathrm{RH}$ level, compared with the other pathogens (Fig. 3). A significant interaction was noted between RH levels and pathogen $(P<0.0001)$. According to AUDPC data, disease severity of plants inoculated with one of the three pathogens and incubated at different RH levels differed significantly for each pathogen $(P<0.0001)$. When plants were inoculated with $P$. agglomerans, mean AUDPC values ranged from 19.6 $\pm 0.8 \mathrm{SE}$ to $29.6 \pm 0.8 \mathrm{SE}$, when incubated at 40 or $100 \% \mathrm{RH}$, respectively (Table 2). According to AUDPC data, when inoculated plants were incubated at 70 or $80 \% \mathrm{RH}$, results were similar. Inoculated plants incubated at $100 \% \mathrm{RH}$ had the highest AUDPC values (Table 2). When plants were inoculated with $P$. ananatis and incubated at $100 \% \mathrm{RH}$, the AUDPC was significantly higher than that for lower 

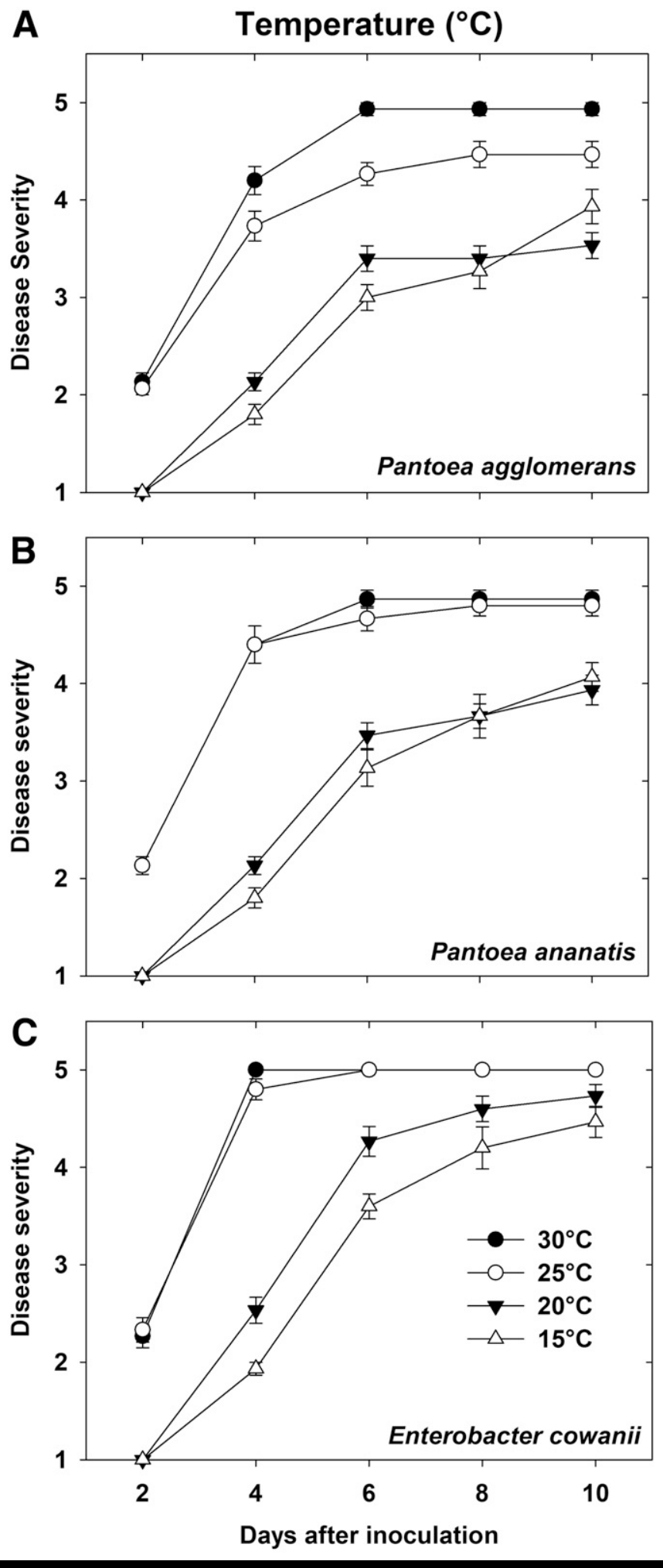

FIGURE 1

The effect of temperature on disease severity over time for onion plants inoculated with A, Pantoea agglomerans, B, P. ananatis, and C, Enterobacter cowanii. Plants were assessed visually for disease severity every other day for 10 days following inoculation using a rating of 1 to 5 to quantify leaf necrosis as follows: $1=<1 \%, 2=1$ to $10 \%, 3=11$ to $25 \%, 4=26$ to $50 \%$, and $5=>50 \%$ (Schwartz 2013).
RH levels (Fig. 4). When $P$. ananatis-inoculated plants were incubated at 70 or $80 \%$ RH, AUDPC values were not significantly different from each other (Table 2). When inoculated plants were incubated at 40 or $60 \% \mathrm{RH}$, AUDPC data indicated similarities in disease severity, but the level of disease was significantly lower than that observed at higher RH levels. When plants were inoculated with $E$. cowanii and incubated at $100 \%$ RH, the AUDPC was significantly higher than those for other RH levels (Table 2). AUDPC values for incubation at 70 or $80 \% \mathrm{RH}$ were $32.7 \pm 1.3 \mathrm{SE}$ and $27.8 \pm 0.9 \mathrm{SE}$, respectively, and differed significantly according to Fisher's protected LSD $(P<0.05)$. Incubation at 40 or $60 \% \mathrm{RH}$ resulted in the lowest AUDPC values, and they were statistically similar to each other according to Fisher's protected LSD $(P<0.05)$ (Table 2). AUDPC values for $E$. cowanii-inoculated plants incubated at 80 or $100 \%$ RH were significantly higher than AUDPC values for plants inoculated with either $P$. agglomerans or $P$. ananatis at the same RH level (Fig. 4). Based on regression analyses, the relationship between AUDPC values and RH was significant, regardless of pathogen, with $R^{2}$ between 0.45 and 0.61 .

\begin{tabular}{|c|c|c|c|}
\hline \multicolumn{4}{|c|}{$\begin{array}{c}\text { TABLE } 1 \\
\text { Effect of temperature on disease severity on onion } \\
\text { plants when inoculated with Pantoea agglomerans, } \\
\text { P. ananatis, or Enterobacter cowanii }\end{array}$} \\
\hline \multirow{2}{*}{$\begin{array}{l}\text { Targeted } \\
\text { temperature }\left({ }^{\circ} \mathrm{C}\right)^{\mathbf{y}}\end{array}$} & \multicolumn{3}{|c|}{ AUDPC } \\
\hline & P. agglomerans & P. ananatis & E. cowanii \\
\hline 15 & $21.1 \pm 0.7 \mathrm{a}$ & $22.3 \pm 1.0 \mathrm{a}$ & $24.9 \pm 0.9 \mathrm{a}$ \\
\hline 20 & $22.4 \pm 0.7 \mathrm{a}$ & $23.5 \pm 0.7 \mathrm{a}$ & $28.5 \pm 0.8 b$ \\
\hline 25 & $33.6 \pm 0.7 b$ & $36.9 \pm 1.0 \mathrm{~b}$ & $39.6 \pm 0.5 \mathrm{c}$ \\
\hline 30 & $37.5 \pm 0.7 \mathrm{c}$ & $37.5 \pm 0.7 b$ & $39.8 \pm 0.4 \mathrm{c}$ \\
\hline
\end{tabular}

${ }^{\mathrm{y}}$ Targeted temperatures set on growth chambers $\left({ }^{\circ} \mathrm{C}\right)$.

${ }^{\mathrm{z}}$ Means of area under disease progress curve (AUDPC) \pm standard error. Means followed by the same letter in each column are not significantly different by Fisher's protected least significant difference $(P \leq 0.05)$.

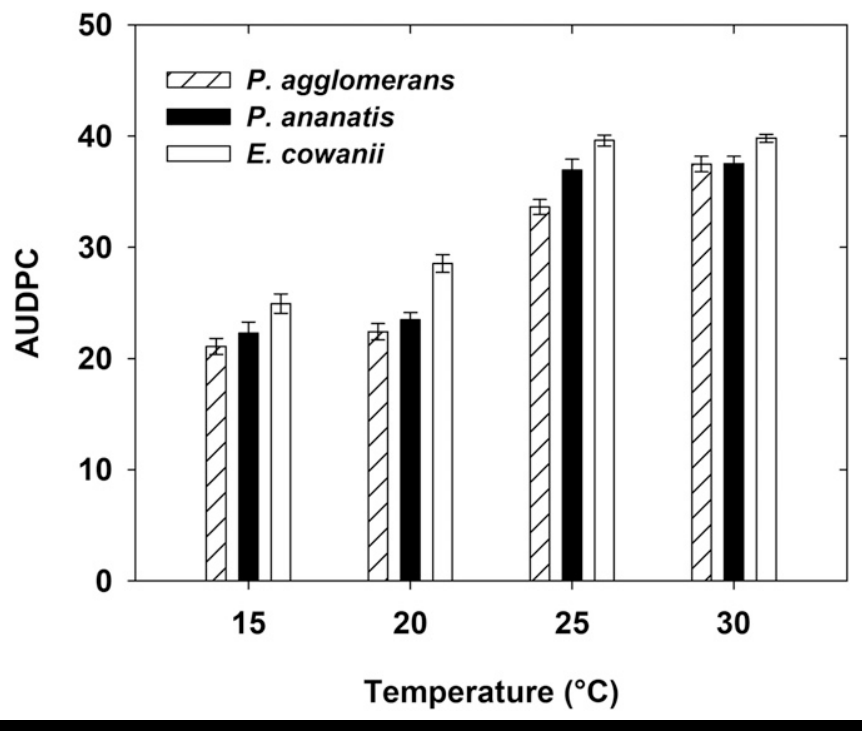

FIGURE 2

Effect of temperature on disease development as indicated by area under the disease progress curve (AUDPC) values from 'Bradley' onion seedlings inoculated with Pantoea agglomerans, P. ananatis, or Enterobacter cowanii at 8 weeks and evaluated for disease symptoms every 2 days from 2 days after inoculation (DAl) until 10 DAl. Vertical bars represent the standard error. 
The relationships between AUDPC and RH were described by the following linear regression equations: $y=0.15 x+12.45\left(R^{2}=0.45\right)$, $y=0.18 x+11.52\left(R^{2}=0.52\right)$, and $y=0.24 x+12.24\left(R^{2}=0.61\right)$ for $P$. agglomerans, $P$. ananatis, and E. cowanii, respectively.
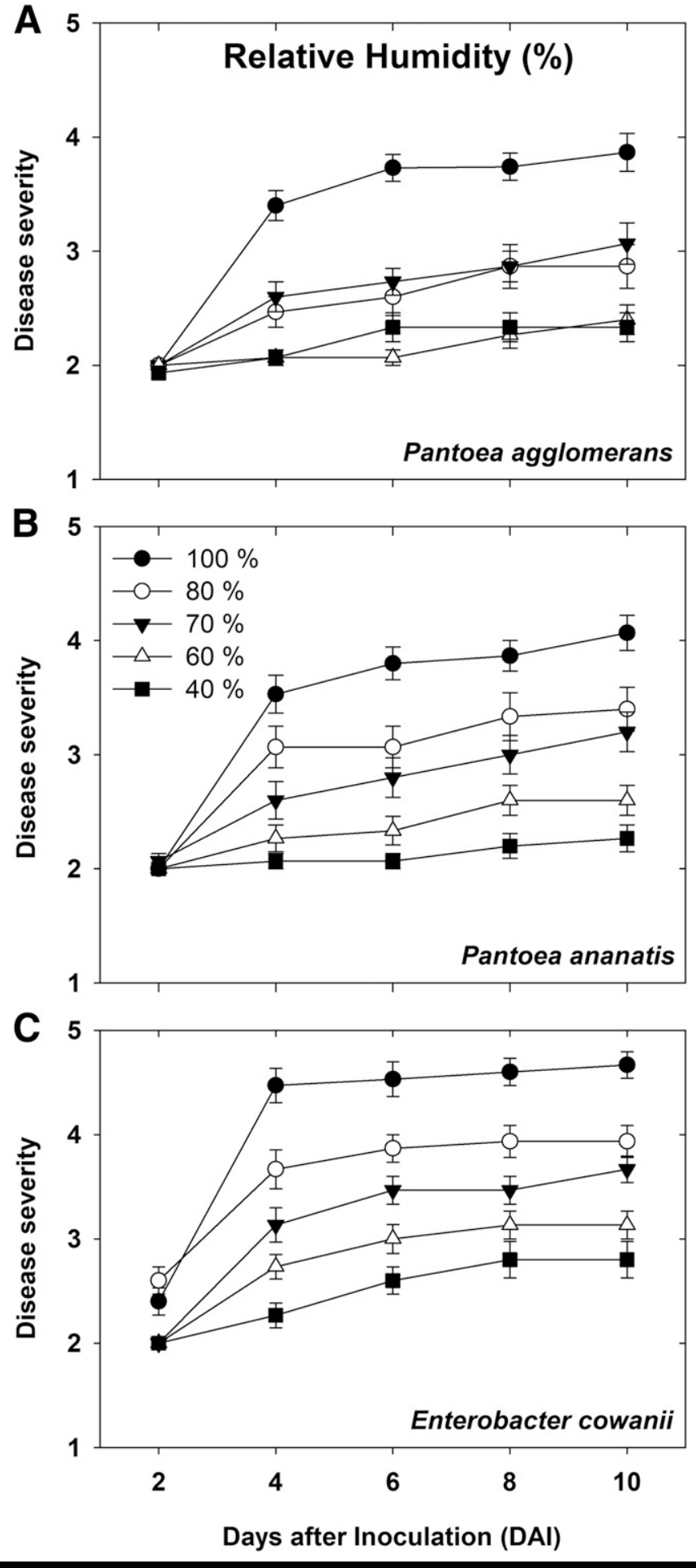

FIGURE 3

The effect of relative humidity on disease severity over time for onion plants inoculated with A, Pantoea agglomerans, B, P. ananatis, and C, Enterobacter cowanii. Plants were assessed visually for disease severity every other day for 10 days following inoculation using a rating of 1 to 5 to quantify leaf necrosis as follows: $1=<1 \%, 2=1$ to $10 \%, 3=11$ to $25 \%, 4=26$ to $50 \%$, and $5=>50 \%$ (Schwartz 2013).
Effect of plant age. Bradley onions were direct seeded into 10cm-square pots (three seeds/pot) containing SUREMIX perlite medium and grown as previously described. Four weeks after seeding, plants in each pot were thinned to one seedling and maintained in a greenhouse to achieve 6-, 8-, 10-, 12-, and 14-weekold plants for inoculation. The inoculation was accomplished as previously described. This experiment was a five-by-four factorial design (plant age $\times$ pathogen). Inoculated plants were arranged in a greenhouse in a randomized complete block design with eight replicate plants. The experiment was repeated. Greenhouse temperatures averaged $23.8 \pm 0.2^{\circ} \mathrm{C}$ in the first replication and $25.9 \pm$ $0.3^{\circ} \mathrm{C}$ in the second replication.

Regardless of plant age, disease symptoms were observed at 2 DAI for all pathogens (Fig. 5). Plant age had a significant effect on disease severity for the three pathogens $(P<0.0001)$. Disease severity progressed quickly as plants aged; most plants aged 12 or

\begin{tabular}{|c|c|c|c|}
\hline \multicolumn{4}{|c|}{$\begin{array}{c}\text { TABLE } 2 \\
\text { Effect of relative humidity (RH) on disease severity of onion } \\
\text { plants when inoculated with Pantoea agglomerans, } \\
\text { P. ananatis, or Enterobacter cowanif }\end{array}$} \\
\hline \multirow{2}{*}{$\begin{array}{l}\text { Targeted } \\
\text { RH }(\%)^{\mathbf{y}}\end{array}$} & \multicolumn{3}{|c|}{ AUDPC ${ }^{z}$} \\
\hline & P. agglomerans & P. ananatis & E. cowanii \\
\hline 40 & $19.6 \pm 0.8 \mathrm{a}$ & $18.9 \pm 0.5 \mathrm{a}$ & $22.1 \pm 0.9 \mathrm{a}$ \\
\hline 60 & $19.2 \pm 0.5 \mathrm{a}$ & $21.0 \pm 0.8 \mathrm{a}$ & $24.9 \pm 0.8 \mathrm{ab}$ \\
\hline 70 & $23.5 \pm 0.8 b$ & $24.2 \pm 1.2 \mathrm{~b}$ & $27.8 \pm 0.9 b$ \\
\hline 80 & $22.7 \pm 1.1 \mathrm{~b}$ & $26.3 \pm 1.3 \mathrm{~b}$ & $32.7 \pm 1.3 \mathrm{c}$ \\
\hline 100 & $29.6 \pm 0.8 \mathrm{c}$ & $30.5 \pm 1.0 \mathrm{c}$ & $37.1 \pm 1.2 \mathrm{~d}$ \\
\hline
\end{tabular}

${ }^{\mathrm{y}}$ Targeted relative humidity (RH) set on growth chambers.

${ }^{\mathrm{z}}$ Means of area under disease progress curve (AUDPC) \pm standard error. Means followed by the same letter in each column are not significantly different by Fisher's protected least significant difference $(P \leq 0.05)$.

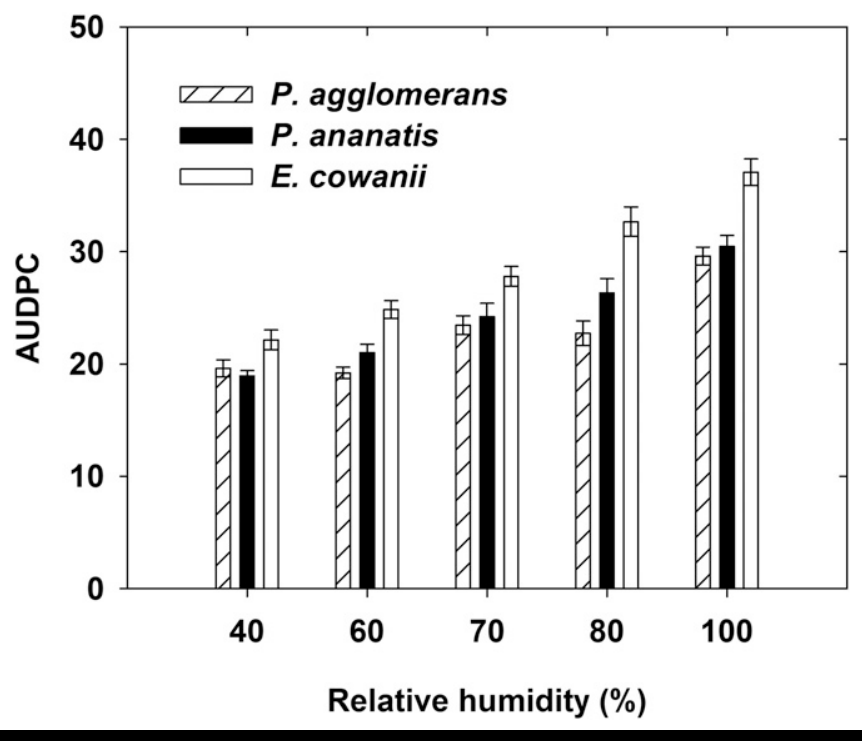

FIGURE 4

Effect of relative humidity on disease development as indicated by area under the disease progress curve (AUDPC) values from 'Bradley' onion seedlings inoculated with Pantoea agglomerans, P. ananatis, or Enterobacter cowanii at 8 weeks and evaluated for disease symptoms every 2 days from 2 days after inoculation (DAI) until 10 DAI. Vertical bars represent the standard error. 
A
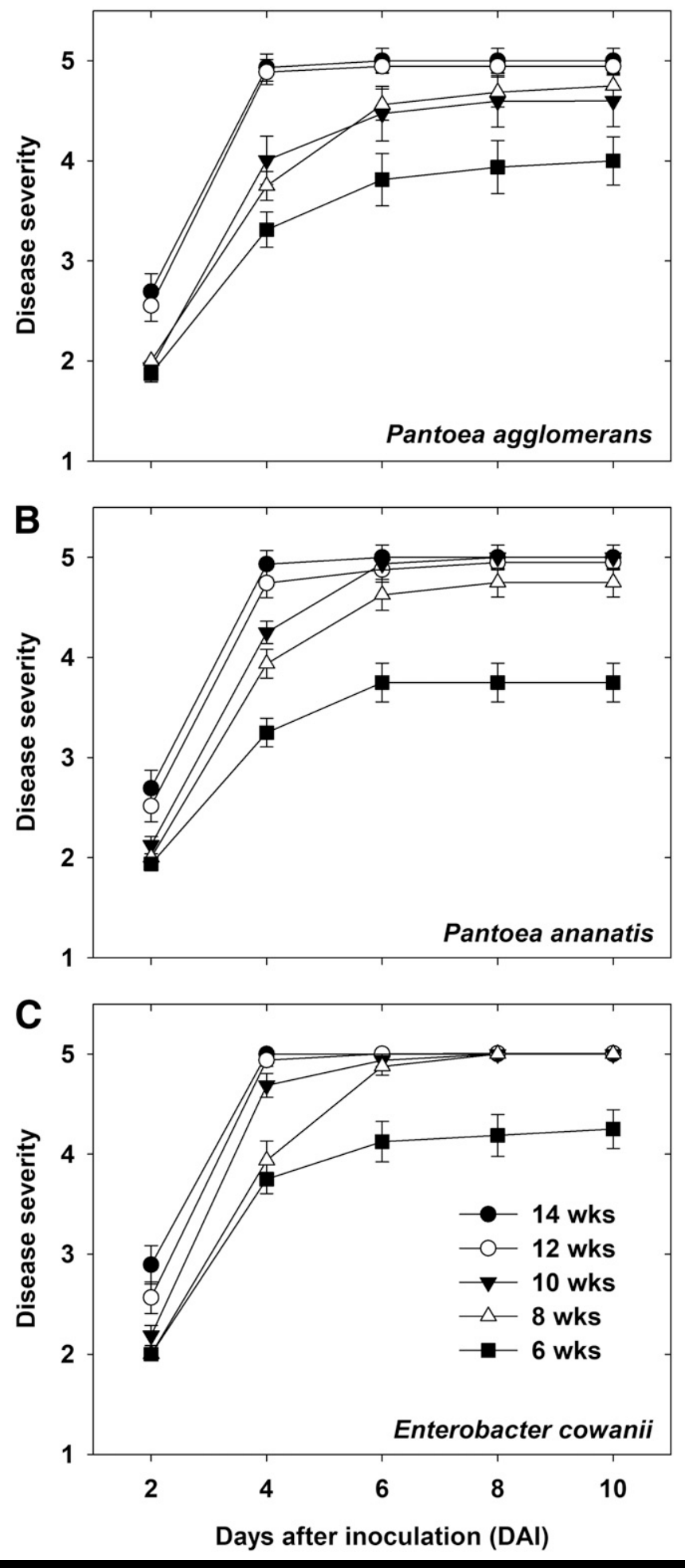

FIGURE 5

The effect of plant age on disease severity over time for onion plants inoculated with A, Pantoea agglomerans, B, P. ananatis, and C, Enterobacter cowanii. Plants were assessed visually for disease severity every other day for 10 days following inoculation using a rating of 1 to 5 to quantify leaf necrosis as follows: $1=<1 \%, 2=1$ to $10 \%, 3=11$ to $25 \%, 4=26$ to $50 \%$, and $5=>50 \%$ (Schwartz 2013).
14 weeks achieved maximum disease severity at 4 DAI (Fig. 5). Plant age-by-pathogen interaction was also significant $(P<0.0001)$. Six-week-old plants had significantly lower AUDPC values compared with older plants (Table 3, Fig. 6). When plants aged 12 or 14 weeks were inoculated, the AUDPC was significantly higher than that of younger plants, but they were not significantly different from each other (Table 3). Strong relationships between AUDPC and plant age were observed for all pathogens when linear regression analysis was applied. The following equations describe these relationships: $y=1.39 x+22.42\left(R^{2}=0.51\right), y=1.40 x+22.49$ $\left(R^{2}=0.53\right)$, and $y=1.13 x+26.72\left(R^{2}=0.54\right)$ for $P$. agglomerans, $P$. ananatis, and E. cowanii, respectively $(P<0.0001)$.

\section{Conclusions and Implications for Disease Management}

The bacterial pathogens, Pantoea spp. and E. cowanii, are relatively new concerns for Michigan's onion producers. In our study, symptoms caused by these pathogens developed under a range of environmental conditions typical during Michigan's growing

TABLE 3
Effect of plant age on disease severity of 'Bradley' onion
plants when inoculated with Pantoea agglomerans,
P. ananatis, or Enterobacter cowanii

${ }^{\mathrm{z}}$ Means of area under disease progress curve (AUDPC) \pm standard error. Means followed by the same letter in each column are not significantly different by Fisher's protected least significant difference $(P \leq 0.05)$.

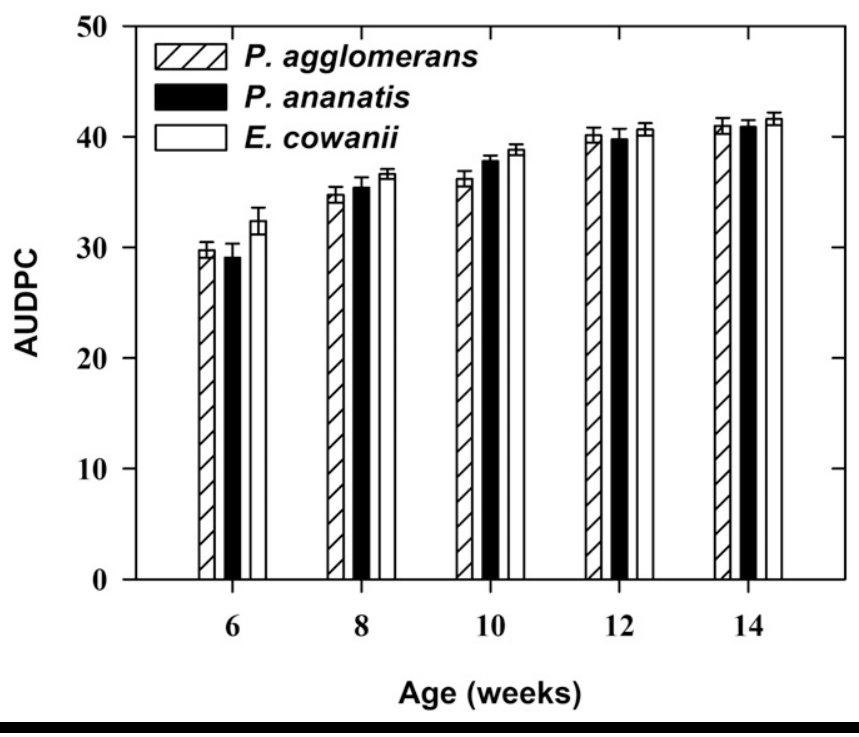

\section{FIGURE 6}

Effect of plant age on disease development when plants were inoculated with Pantoea agglomerans, P. ananatis, or Enterobacter cowanii. Results are means of area under disease progress curve (AUDPC) with 16 replicated plants for each age. Data from repeated experiments were combined. Vertical bars represent the standard error. 
season. Disease severity increased with both increasing temperature and $\mathrm{RH}$, whereas disease progression was restricted under cool temperatures $\left(15^{\circ} \mathrm{C}\right)$ and low RH (40 to $\left.60 \%\right)$. Severity of disease symptoms on onion foliage was influenced by temperature, $\mathrm{RH}$, and plant age. Older plants in post bulb-growth stage, incubated between 25 and $30^{\circ} \mathrm{C}$ at $>80 \% \mathrm{RH}$, exhibited increased disease severity according to AUDPC data. In Colorado, Schwartz et al. (2003) noted a relationship between temperature and rainfall in the development of leaf blights of onion caused by Xanthomonas sp. and Pantoea sp. The severity of disease associated with these pathogens increased dramatically with conditions of 28 to $35^{\circ} \mathrm{C}$ and high cumulative rainfall during the bulbing stage (Schwartz et al. 2003). Similarly, temperatures of 25 to $30^{\circ} \mathrm{C}$ and $\mathrm{RH}$ of 85 to $95 \%$ contributed to an outbreak of Xanthomonas leaf blight in onion in the Caribbean (Paulraj and O'Garro 1993). The effect of temperature and RH on bacterial soft rots in onions caused by Dickeya, Erwinia, Pectobacterium, and Pseudomonas species have also been noted (Schwartz 2013); warm temperatures and RH greater than $70 \%$ favor disease development in storage. For Enterobacter bulb decay incited by $E$. cloacae, disease development is exacerbated by curing temperature above $94^{\circ} \mathrm{F}\left(\sim 34^{\circ} \mathrm{C}\right)$ (Schroeder and du Toit 2010). In our study, optimum temperatures for disease development were 25 to $30^{\circ} \mathrm{C}$. The temperature of $35^{\circ} \mathrm{C}$ included in the study by Schwartz et al. (2003) was not included in our study because temperatures $\geq 35^{\circ} \mathrm{C}$ are not typical during Michigan's growing season. Based on regression analyses for the effect of temperature and RH, our study agrees with Schwartz et al. (2003); when temperature and RH increases, disease develops faster. In addition, according to our study, disease severity was maximized under temperatures of 25 and $30^{\circ} \mathrm{C}$.

Bradley onion used in our study is a long-day Spanish type with a relative maturity of approximately 118 days. Plant ages tested in our trial ranged from 6 weeks (three to four true leaf stage) to 14 weeks (post-bulb-growth stage) (Schwartz 2013). In the field, Schwartz (2013) found that bacterial disease incidence increased in late June or early July, approximately 10 weeks after planting. Our results support this observation, because the disease symptoms were significantly more severe when plants were inoculated at an age of 10 versus 6 weeks. AUDPC values also indicated that disease symptoms were more severe when plants were inoculated at an age of 12 or 14 weeks. This is further supported by a recent study that found $P$. ananatis foliar infection led to high levels of storage rot when plants were inoculated approximately 12 to 14 weeks after planting (Stumpf et al. 2017).

Age-related resistance studies in onion include purple blotch incited by Alternaria porri, because mature leaves are more susceptible to $A$. porri than younger leaves (Miller 1983). Wiriyajitsomboon (2015) found that susceptibility to onion pink root, incited by Setophoma terrestris, increases with age. However, Cramer (2000) reported that older onion plants were less susceptible to Fusarium basal rot, incited by Fusarium oxysporum f. sp. cepae, than seedlings.

A recent Michigan study has shown that copper-based bactericides alone do not provide effective protection from foliar bacterial diseases in onion (Grode et al. 2019). Limiting thrips populations is important to reduce foliar disease symptoms caused by $P$. agglomerans (Grode et al. 2019). This study builds upon these recommendations by emphasizing the management of thrips and bacterial diseases through the later post-bulb-development stages to limit late-season disease epidemics. By continuing management through these later stages, bulb rot in storage could also be limited. Also, because temperatures of 25 to $30^{\circ} \mathrm{C}$ and high $\mathrm{RH}$ levels $(>80 \%)$ may exacerbate $P$. agglomerans, $P$. ananatis, and
E. cowanii infestations, management strategies should ensure plants are well protected when these conditions occur.

\section{Acknowledgments}

Gratitude goes to S. Courtney and B. Harlan for their assistance.

\section{Literature Cited}

Beer, S. V., Zaid, A. M., and Bonasera, J. M. 2010. Studies of bacterial problems of onion in New York - 2010. Department of Plant Pathology and PlantMicrobe Biology, Cornell University, Ithaca, NY. http://www.hort.cornell.edu/ expo/proceedings/2011/Onions $\% 20 \& \% 20 \mathrm{Garlic} / \mathrm{STUDIES} \% 20 \mathrm{OF} \%$ 20BACTERIAL\%20PROBLEMS $\% 20$ OF\%20ONION\%20IN\%20NEW\% 20YORK.pdf

Brady, C., Cleenwerck, I., Venter, S., Vancanneyt, M., Swings, J., and Coutinho, T. 2008. Phylogeny and identification of Pantoea species associated with plants, humans and the natural environment based on multilocus sequence analysis (MLSA). Syst. Appl. Microbiol. 31:447-460.

Brady, C. L., Venter, S. N., Cleenwerck, I., Engelbeen, K., de Vos, P., Wingfield, M. J., Telechea, N., and Coutinho, T. A. 2009. Isolation of Enterobacter cowanii from Eucalyptus showing symptoms of bacterial blight and dieback in Uruguay. Lett. Appl. Microbiol. 49:461-465.

Carr, E. A., Bonasera, J. M., Zaid, A. M., Lorbeer, J. W., and Beer, S. V. 2010. First report of bulb disease of onion caused by Pantoea ananatis in New York. Plant Dis. 94:916.

Cramer, C. S. 2000. Breeding and genetics of Fusarium basal rot resistance in onion. Euphytica 115:159-166.

De Baere, T., Verhelst, R., Labit, C., Wauters, G., Claeys, G., Verschraegen, G., and Vaneechoutte, M. 2004. Bacteremic infection with Pantoea ananatis. J. Clin. Microbiol. 42:4393-4395.

Edens, D. G., Gitaitis, R. D., Sanders, F. H., and Nischwitz, C. 2006. First report of Pantoea agglomerans causing a leaf blight and bulb rot of onions in Georgia. Plant Dis. 90:1551.

Furtado, G. Q., Guimarães, L. M. S., Lisboa, D. O., Cavalcante, G. P., Arriel, D. A. A., Alfenas, A. C., and Oliveira, J. R. 2012. First report of Enterobacter cowanii causing bacterial spot on Mabea fistulifera, a native forest species in Brazil. Plant Dis. 96:1576.

Gitaitis, R. D., and Gay, J. D. 1997. First report of a leaf blight, seed stalk rot, and bulb decay of onion by Pantoea ananas in Georgia. Plant Dis. 81:1096.

Gitaitis, R. D., Walcott, R., Culpepper, S., Sanders, H., Zolobowska, L., and Langston, D. 2002. Recovery of Pantoea ananatis, causal agent of center rot of onion, from weeds and crops in Georgia, USA. Crop Prot. 21: 983-989.

Grode, A. S., E.Brisco-McCann, P.Wiriyajitsomboon, M. K.Hausbeck and Z.Szendrei. 2019. Managing onion thrips can limit bacterial stalk and leaf necrosis in Michigan onion fields. Plant Dis. 103:938-943.

Gugino, B. K., and Pfeufer, E. E. 2015. Bacterial disease management of onions. Department of Plant Pathology and Environmental Microbiology, Penn. State University, University Park, PA. https://www.paorganic.org/bacterialdisease-management-of-onions

Hausbeck, M. K. 2014. Newly identified bacterial disease on onions. Michigan State University Extension, East Lansing, MI. https://www.canr.msu.edu/ news/newly_identified_bacterial_disease_on_onions.

Jeger, M. J., and Viljanen-Rollinson, S. L. H. 2001. The use of the area under the disease-progress curve (AUDPC) to assess quantitative disease resistance in crop cultivars. Theor. Appl. Genet. 102:32-40.

Mark, G. L., Gitaitis, R. D., and Lorbeer, J. W. 2002. Pages 267-292 in: Allium Crop Science: Recent Advances. H. D. Rabinovich and L. Currah, eds. CAB International, Wallingford, U.K.

Miller, M. E. 1983. Relationships between onion leaf age and susceptibility to Alternaria porri. Plant Dis. 67:284-286.

National Onion Association (NOA). 2016. How and where onions are grown: Domestic onion production. https://www.onions-usa.org/all-about-onions/ where-how-onions-are-grown

Paulraj, L., and O'Garro, L. W. 1993. Leaf blight of onions in Barbados caused by Xanthomonas campestris. Plant Dis. 77:198-201.

Pfeufer, E. E. 2014. Sources of Inoculum, Epidemiology, and Integrated Management of Bacterial Rots of Onion (Allium cepa) with a Focus on Center Rot, Caused by Pantoea ananatis and Pantoea agglomerans. Ph.D. diss., Pennsylvania State University, University Park, PA. https://etda.libraries.psu.edu/ files/final_submissions/9951

Schroeder, B. K., and du Toit, L. J. 2010. Effects of postharvest onion curing parameters on Enterobacter bulb decay in storage. Plant Dis. 94:1425-1430.

Schwartz, H. F. 2013. Onion Health Management and Production. Colorado State University Press, Fort Collins, CO. 
Schwartz, H. F., and Mohan, S. K. 2008. Compendium of Onion and Garlic Diseases and Pests, 2nd Ed. American Phytopathological Society, St. Paul, MN.

Schwartz, H. F., and Otto, K. 2000. First report of a leaf blight and bulb decay of onion by Pantoea ananatis in Colorado. Plant Dis. 84:808.

Schwartz, H. F., Otto, K. L., and Gent, D. H. 2003. Relation of temperature and rainfall to development of Xanthomonas and Pantoea leaf blights of onion in Colorado. Plant Dis. 87:11-14.

Stumpf, S., Gitaitis, R., Coolong, T., Riner, C., and Dutta, B. 2017. Interaction of onion cultivar and growth stages on incidence of Pantoea ananatis bulb infection. Plant Dis. 101:1616-1620.

Tho, K. E., Brisco-McCann, E., Wiriyajitsomboon, P., Sundin, G., and Hausbeck, M. K. 2019. Bacteria associated with onion foliage in Michigan and their copper sensitivity. Plant Health Prog. 20:170-177.
Tho, K. E., Wiriyajitsomboon, P., and Hausbeck, M. K. 2015. First report of Pantoea agglomerans causing onion leaf blight and bulb rot in Michigan. Plant Dis. 99:1034.

Walcott, R. R., Gitaitis, R. D., Castro, A. C., Sanders, F. H., Jr., and Diaz-Perez, J. C. 2002. Natural infestation of onion seed by Pantoea ananatis, causal agent of center rot. Plant Dis. 86:106-111.

Wiriyajitsomboon, P. 2015. Characterization of Setophoma terrestris Causing Pink Root in Onion, Disease Management and Age-Related Resistance. Ph.D. diss. Department of Plant, Soil and Microbial Sciences, Michigan State University, East Lansing, MI. ProQuest no. 3739571.

Wright, P. J., and Grant, D. G. 1998. Evaluation of Allium germplasm for susceptibility to foliage bacterial soft rot caused by Pseudomonas marginalis and Pseudomonas viridiflava. N. Z. J. Crop Hortic. Sci. 26:17-21. 